\title{
The Implementation Formula of Entrepreneurship Education at Higher Education as A Solution for the Social Problem
}

\author{
Lailatussaadah ${ }^{1}$, Asyraf Isyraqi Bin Jamil ${ }^{2}$ \& Fakhrul Adabi Bin Abdul Kadir ${ }^{3}$ \\ 1 University of Malaya and Lecturer Departement of Islamic Education Management, Faculty of Tarbiyah and \\ Teacher Training, UIN Ar-Raniry Banda Aceh, Indonesia \\ 2 Departement of Islamic Education, Academy of Islamic Studies, University of Malaya, Kuala Lumpur, Malaysia \\ ${ }^{3}$ Departement of Dakwah and Human Development, Academy of Islamic Studies, University of Malaya, Kuala \\ Lumpur, Malaysia \\ Correspondence: Lailatussaadah, University of Malaya and Lecturer Departement of Islamic Education Management, \\ Faculty of Tarbiyah and Teacher Training, UIN Ar-Raniry Banda Aceh, Indonesia.
}

Received: July 17, 2020

doi:10.5430/ijhe.v9n6p10
Accepted: August 5, 2020

Online Published: August 17, 2020

URL: https://doi.org/10.5430/ijhe.v9n6p10

\begin{abstract}
s
This research aims at finding out the implementation formula of entrepreneurship education at the university. The searching of electronic journal articles by using database such as: JSTOR, SAGE, Proquest, Elsevier, Emerald Insigth, and Google Scholar from 2009 until the end of October 2019. The keywords: entrepreneurship education, entrepreneurial and unemployment. The implementation formula of entrepreneurship education is done through the curriculum reformations and improvements, the creation of extracurricular activities and entrepreneurship programs, the empowerment of human resource development for entrepreneur lecturer (teachers), the adequacy of infrastructures and financial supports, the strengthening of cooperation with associates, the alumni empowerment and also the support of government. The implementation formula of entrepreneurship education at the university is able to shape the character, improve the habits, attitude, and the passions of the university students to be entrepreneurs and also increase the number of new entrepreneurs in Indonesia that will be a solution of intellectual unemployment problems.
\end{abstract}

Keywords: education, entrepreneurship, intellectual, social problem, unemployment

\section{Introduction}

Entering the era of industrial reform of 4.0, Indonesia seriously develops the entrepreneurship as one of the policies in the operation of the higher education in the country. Considering this issue, starting from the implementation of Indonesia Qualification Framework Curriculum $(K K N I)$, the basic creation of $K K N I$ is the gap quality of human resources in Indonesia, for example between the quality of human resources in Java and outside Java, among the quality of human resources in large cities and villages, among graduates of one university with other universities, etc. Another reason is the existence of inequality between the high school's human resources standards with the quality needed in the workforce. Thus, the effect is that more and more university graduates are unemployment. Entrepreneurship has become a subject to learn at the university. Yet, the paradigm of Tri Dharma University (Tri Dharma Perguruan Tinggi) must be synchronized with the industrial era 4.0; they are three new literatures including: 1. Digital, technology and human, 2. extracurricular activity for the leadership and teamwork development, 3. Entrepreneurship and internship to be obligated (Slamet, 2019). The application of Tri Darma University in Indonesia must be in line with the industrial era by integrating the three components of literatures as meant by Slamet. The integration of entrepreneurship into one of the obligatory activities shows that the university should analyze the programs available at the institution.

The purpose of the entrepreneurship education at the university in Indonesia is to enhance students' entrepreneurial intention which result in the decrease of unemployment case. The release of statistical Bureau Agency (BPS) 2019 found that the increase number of unemployment of diploma and university graduate caused by the irrelevancies (mismatch) between the skills and the need of higher status and income expectations, and also limited number of jobs available. For the level of diploma, the number is increased into $8.5 \%$, in the year of 2017 only 6 , $4 \%$ of unemployment but in 2019 increased into $6.9 \%$ while the number of unemployment for university increased for $25 \%$ 
in the year 2017 per February 5.0\% to be $6.2 \%$.

The above number is pitiful comparing the decrease number of unemployment rate at the Senior High School level (SMA) for (7.92\%) and SMK (10.42\%) (BPS, 2019). On the other hand, the job potencies in Indonesia is now being replaced by the digital systems for about 52, 6 million (McKinsey). Then, the industrial revolution industry will automatically strike out 35 percents of job in the next coming five years even will increase 75 percents in the next ten years (Dwikorita Karnati, 2017, maulana Ahmadnur, 2019; Nandarizkaa, 2019), the presence of working stigma is to be government employee (PNS) (Kamaruzaman Bustamam Ahmad, 2014), and based on the data of BKN, the number of applicant reached the total of 31.686 people in 2019. The fact of increasing number of unemployment from the university graduates and the potencies of working fields that will be taken by the digital systems is becoming a serious problem that must be handled immediately especially through the education. Thus, the entrepreneurship education formula should be found.

The researchers agree that entrepreneurship education is able to provide positive contributions and grow the entrepreneurial soul. Indrayani opines that entrepreneurship education is all activities aimed at growing up the thought or mindset about entrepreneurship, passion, attitude and someone's competencies in developing his potentials factors by carrying out creative and innovative behavior (Ratih Indrayani, 2017). Whilst, Mila said that entrepreneurship educations is one of the ways to develop academic situation in relation with the shaping of character of the graduates of high education institutions (Ratih Indriyani, 2017), Milla, 2013). The entrepreneurship education implemented in Indonesia so as to grow the entrepreneurial soul and to increase the number of new entrepreneur range at the minimum of $2 \%$ the total of population in Indonesia that will end up at the decrease number of intellectual unemployment (Hussain \& Othman, 2013; Pratama, 2010)

One of the special concerns of the academicians related to this issue is the integration of entrepreneurship as a subject. Therefore, entrepreneurship practice is a solution applied by the government in Indonesia to overcome the unemployment problem nowadays (Hasan Basri M. Nur and Ahmad Zaki Husaini, 2017; Milla,2013; Siswoyo, 2009). The purpose of this study is the existence of entrepreneurial soul through the academicians, coaching, mentoring, consultancy and industrial expert (Khairul Anwar, 2016; Malez and katzenbatch in Wibowo 2007). Recently, the entrepreneurship education becomes a strategic issue as well as a trending discussion topic in the numbers of academic meetings, seminars, journals and books in order to overcome the unemployment problem.

Based on the above data, it is important to implement the entrepreneurship education at the high education level in a systemic and systematically way, "So the graduates must possess the character building, employability skill and entrepreneurship skill as the solution to overcome the unemployment problem" Anwar (in Siprianus edi Hardun/ EHD, 2016). "Because, with the existence of entrepreneurial education will establish the motivation of entrepreneurship" (Ratih Indrayani, 2017)

The aim of this research is to conduct a review on some literatures about the implementation formula of the entrepreneurship education to bring about the entrepreneurial soul of the university student. It is hoped that this formula can be applied effectively and bring about a recommendation for other Islamic higher education Institutions at all aspects and fields. Therefore, the process of entrepreneurship education can contribute to decrease the number of unemployment of the university graduates as well as to increase the number of educational entrepreneurships.

\section{Method}

This research method used is a library of research. The method used in finding the articles done through the electronic way by using some Scopus indexed databases, they are SAGE, Science Direct, Proquest, Elsevier, Emerald Insight, Google Scholar from 2007 until the end of October 2019 by using the keyword entrepreneurship education and entrepreneurial, unemployment. Then, the result of the article searching on those engines was reviewed and selected based on the purpose of this research that is to find out the implementation formula of entrepreneurship education at the high education level (university). The article used as a sample was then identified. Only selected relevant articles will be presented in the following table. From various literature, it will be used as an input to the pattern of higher education in Indonesia, especially in the Faculty of Teacher Training of Education in applying education entrepreneurship.

Those selected relevant articles that were analyzed consist of fifteen articles regarding the implementation of entrepreneurship education in the private, state, public, and Islamic universities. The article was then reviewed under the theme of the implementation formula of entrepreneurship education at higher education. 


\section{Result and Discussion}

\subsection{Result}

The study about the entrepreneurship education has been conducted by many researchers previously. It was carried out by asking questions, using analyzing method, determining the research finding, drawing conclusion and recommendation. Those previous studies are expected to strengthen and be comparable, identical and interconnected with this study. The first article, Patrick \& Co found that the entrepreneurship education in Tunisia is done by reforming the curriculum in order to construct the entrepreneurship track that provides the training (Nur et al., 2015; Patrick Premand at.al, 2016)

The second ones, Sipitanou \& Co found that the entrepreneurship education conducted in Greece as one of the efforts to acquire the fundamental mental transformation and to establish an entrepreneurial culture as a means of unemployment problem. The entrepreneurship education is done by organizing the training and entrepreneurship course in the field of economy and business, in spite of some obstacles in terms of incomplete curriculum integration (Chengalvala et al., 2017; Siswoyo, 2009) Sipitanau \& Papagianis, 2013).

The Third article, Zhang Lili found that entrepreneurship education that is carried out through practical approach is able to establish good entrepreneurship environment, empower the trainer of entrepreneurship lecturer, construct the entrepreneurship consultant team and develop the entrepreneurship research (Sulaiman, 2017; Zhang Lili, 2011). This article explains nothing regarding the obstacles in the implementation of entrepreneurship education.

The fourth article, Milla determined that the implementation of entrepreneurship education is done through the activity of the so-called "Tri Darma University" (Teaching, Research and Community Dedication). The lecturers transfer the entrepreneurship education value through the teaching learning activity. The lecturer research activity may open an opportunity for the university students to access the field laboratories and involve in the innovative community dedication program. Thus, an entrepreneurship in the basis of knowledge, technology for Innovation and creativity (IbIKK) can be developed. This article discusses nothing about the problem found in its implementation. (Milla, 2013)

The fifth article, Sentoso said that the implementation of entrepreneurship education is carried out through (1) The entrepreneurship training workshop for the active students as well as alumnus; (2) The education curriculum transformation in Indonesia in order to be relevant with the new paradigm in facing the global competencies on the need of education nowadays. (3) Entrepreneurship award program in the form of business plan or expo, (4) Human resource development program for lecturer, entrepreneurship and students workshop center and the cooperation with DUDI. No obstacles are discussed in this article (Sentoso, 2012).

The sixth article, Eriawaty \& Co opined that the entrepreneurship education implemented by teaching the subject focusing on deepening the theory and direct practice. Besides, the entrepreneurship education can be implemented through the Tri Dharma University, they are; education, research and community dedication. Whilst, the obstacles found on the implementation is due to the discourage of a number of students in taking the risks (Eriawaty and Fitriyanti, 2016).

The seventh article, Pratama found that the implementation of entrepreneurship education has been carried out by establishing the entrepreneurship center that designs strategy and entrepreneurship teaching concept, they are: (1) case studies, studying some business cases like the goggle corp that was forced to leave China due to the high level of hacking. (2) The speech by guest speaker (practical) of business field, delivered at the general or first lecturing. The speaker may be the one of young businessman and some discussion sessions are provided in this activity. (3) The teaching of the project design and consultation. (4) The study of business plan design (venture plan writing) as the final assignment by including all aspects like product innovation, financial projection, capital, marketing of the product or service, market analysis, employee and permits. (5) The study about business starting up (coaching). In this activity, the students are trained by the entrepreneur lecturer to be able to become an entrepreneur. (6) The teaching through computer simulation as media to go through the business world. Taking an example, the using http://www.tombongantuk.com. This game takes the students to be newcomers of business world. (7) The visit study methods at the enterprise company in order to have a direct observation toward the business activity and process. (8) the launching of short movie or video about entrepreneurship. (9) The supports in extracurricular. (10) The similar mind set of lecturers. (11) Curriculum integrated entrepreneurship, (12) The Clustering of the students based on the entrepreneurial skill. Whilst, the obstacles in the implementation of the entrepreneurship education is in terms of the perception that this program is time and fund consuming. (Pratama, 2010).

The eighth articles, Merle opined that the implementation of entrepreneurship education conducted by establishing 
the public course about the entrepreneurship, financial attempts, family enterprise, social entrepreneurship, business plan and network opportunity. While the operational obstacle is related to the limitation of human resource (Lubis, 2015; Merle Kuttim at.al, 2013; Patrick Premand at.al, 2016; Pratama, 2010; Schuitema, Jaap, Geert ten Dam, 2008).

The ninth articles, Ratih Indriyani shown that the implementation of entrepreneurship education is largely depending on the lecturer competency. In this context, the lecturers are expected to conduct more practical than theoretical approaches. The obstacle of the implementation is seen on the incapability to grow the entrepreneurship passion (Merle Kuttim at.al, 2013; Pratama, 2010; Ratih Indriyani, 2017)

The tenth article, Siswoyo found that there are some ways to conduct the entrepreneurship education, they are through: (1) Systematical Entrepreneurship lecturing by allocating the adequate SKS, (2) Real Work Lectures (KKN)- attempts by providing the students with ability, skill, managerial expertise, technology and innovation adoption, marketing skill through the direct experience in the business world, (3) business consultation clinic and job placement center (KBKP), which is one of the US-AID and HEDS support program . This program was basically a development of the consultation center for the micro and high level of businessman as one of the attempt to provide the service toward the alumnus of the university who possess strong passions to become new businessman, or the micro level of businessman who have been involved in the business world. In addition, the KBKP also educates the teaching staff so as to have some practical experiences in business by providing consultation.

The KBKP also leads some access to the material, financial, information resource, market and building the job network. (4) The entrepreneurship internship. Through this program, the students are actively involved by working as employee at the micro or high scale of business in order to obtain some practical working experiences concerning the problem identification, problem analysis and solving, management, marketing and technology. The internship also provides the link and match among the higher education and micro and high level of DUDI and the teaching staff as the advisor. (5) Students' innovative work. This program exists as an attempt to synchronize the students' knowledge, technology and information and skill to produce the product with the business understanding. This program is prioritized for the student's productive activity as an integral part of the intra or extracurricular activity. (6) The new entrepreneurship incubation. This program appears as a cooperative media between the university and the office of the minister of cooperatives and the coaching of small entrepreneurs.

The program organized by the limited staffs offer a certain package for the entrepreneurs, students and alumni such as infrastructure provision, Access opportunity (IT), consultation service (technology, management and marketing aspects), working network establishment among the entrepreneurs and the development of research product for the commercial production. This program was developed by Dirjen Dikti in 2019 as a student entrepreneur program, (7) workshop role models by motivating the students and graduates to take into account that becoming an entrepreneurs, there are some aspects to consider about, they are the opportunity, freedom and life satisfaction factor. (8) The availability of entrepreneurship coach lecturer. This is a strategic role in the effort to equip entrepreneurship for students not only in the cognitive aspect but greater in terms of practical aspect.

Some programs are not applicable due to the lack of human resource and financial source. The obstacle in the implementation is due to theless number of the human resource and incomplete facilities. The obstacle in terms of the lecturer competencies is the limited number of coach lecturer availability. It is urged that the lecturers acquire some education, training and internship empowerment. The empowerment carried out by the general directory of high education depdiknas in cooperation with the university in the entrepreneurship center program aiming at producing the graduates of university who are ready to face the working field (Chengalvala et al., 2017; Pratama, 2010; Wiratno, 2012), Siswoyo, 2009

The eleventh article, Siswo Wiranto found that the purpose of entrepreneurship education is to shape the students' attitude, develop the skill and provide the knowledge. By the entrepreneurship education program through the education and training, it can shape the challenge experience and risk management ability as an employee or employer at the certain field of work. The entrepreneurship education can be implemented through (1) delivering the entrepreneurial materials by learning by doing, instead of simulation, (2) conducting the curriculum update oriented on the demand driven such as academic knowledge, analytical skill, managerial skill and communication skill, (3) improving the lecturer competency, providing the extra skills like life skill and the adaptation and socialization skill ( soft skill) ability toward the working environment and posses the passion of life -long education. (4) Undertaking a minimum service standard in running the entrepreneurship education program to achieve an optimal pattern goal (5) Maximizing the application of the Presidential Decree number 6, 2009 about the creative economy covering all required aspects such as (a) the evaluation and empowerment of the KBPK program, (b) It is important that the high education conduct a well-planned, step by step and continue planning in providing the infrastructures to support the 
success of the entrepreneurship education at a number of Study program (Prodi) and building a coordination and cooperation or job network with DUDI as the university partner and alumni empowerment. While the obstacles are found as follow (1) the preparation and implementation of the entrepreneurship education and the new unit role as the entrepreneur organizer are still considered in optimal. (2) The limit provision of infrastructure provider, working partner, fund and competent lecturer in providing the content of entrepreneurship skill (Sentoso, 2012; Zhang Lili, 2011) Wiratno, 2012).

The twelfth articles, Lubis said that the implementation of entrepreneurship education can be done through the triple 1 model (1) the "power of one nation" challenge, a model applied through the mentor scheme provided by the guest and teaching lecturer. This power will bring about variety fields of entrepreneurship such as technopreneur, sociopreneur, edupreneur, creativepreneur and digipreneur. (2) the financial aid challenge, that is regarded as the problems for all entrepreneurship education stake holders. Regarding this, the strong commitment and support of the government is highly required as a process of designing the future of Indonesia by teaching the entrepreneurial generation. (3) The "world class label" effect, which contributes greatly to the success of implementation of entrepreneurship education by establishing the international cooperation. Above all, the most essential points are the commitment, bravery and the brilliant ideas of the lecturer. While the obstacles in the implementation are found in terms of the government funding, the poor mastery of foreign languages and the human recourse commitment.

The thirteenth articles, (martin, Bruce C. Jeffredy J. McNally, 2013) found that the design of effective human capital through the entrepreneurship education and training (EET) has gained the government attention due to the fast growth of the EET all over the world. But somehow, it is piteous that there are less consistent evident that shows the effectiveness of EET in creating more and better entrepreneurship education.

The fourteenth articles, Nur at al, stated that the entrepreneurship education is applied through the Technical and Vocational Education and Training (TVET). The entrepreneurial education curriculum has always to be developed so as to be able to increase the entrepreneurial culture. Thus, it is able to rise up the students' passion in determining the entrepreneurship as the future carrier field. The government involvement can be done through the provision of facility to motivate the society in general and youth in specific (Nur et.at.,2015)

The fifteenth article, Sarada Chengalvala \& Co identified that the entrepreneurship education in the university is carried out by organizing the programs, activities and workshops related to the entrepreneurship, creating the real business experience. Raising the support from family, colleagues and religious figures (Chengalvala et.al,.2017).

\subsection{Discussion}

This Paper discusses there are 15 manuscripts of journal analysis that discuss the implementation strategy of entrepreneurship-based education in university. Described in the following table form the searching of electronic journal articles by using database such as: JSTOR, SAGE, Proquest, Elsevier, Emerald Insigth, and Google Scholar from 2009 until the end of October 2019.

Journal Analysis

Table 1. The Implementation of Enterpreneurship Education at the University

\begin{tabular}{|c|c|c|c|c|}
\hline No & $\begin{array}{l}\text { Researcher\&Ye } \\
\text { ar }\end{array}$ & Topic & $\begin{array}{l}\text { Journal } \\
\text { Title }\end{array}$ & $\begin{array}{l}\text { The finding of the implementation } \\
\text { form }\end{array}$ \\
\hline 1 & $\begin{array}{l}\text { (Patrick } \\
\text { Premand at.al, } \\
\text { 2016) }\end{array}$ & $\begin{array}{l}\text { Entrepreneursh } \\
\text { ip Education } \\
\text { and Entry into } \\
\text { Self } \\
\text { Employment } \\
\text { Among } \\
\text { university } \\
\text { Graduates }\end{array}$ & $\begin{array}{l}\text { Juornal } \\
\text { World } \\
\text { Development } \\
\text { · Elsevier }\end{array}$ & $\begin{array}{l}\text { Conducting the curriculum reform to } \\
\text { create the entrepreneurship pathway that } \\
\text { provides the training. }\end{array}$ \\
\hline 2 & $\begin{array}{l}\text { (Sipitanou \& } \\
\text { Papagiannis, } \\
\text { 2013) }\end{array}$ & $\begin{array}{l}\text { Education, } \\
\text { Entrepreneursh } \\
\text { ip and } \\
\text { Entrepreneuria } \\
\text { 1 Activation: A } \\
\text { Challenge for }\end{array}$ & $\begin{array}{l}\text { International } \\
\text { Journal of } \\
\text { arts } \quad \& \\
\text { Sciences }\end{array}$ & $\begin{array}{l}\text { The entrepreneurship training and course } \\
\text { are conducted in business study and } \\
\text { economy. }\end{array}$ \\
\hline
\end{tabular}


All

$3 \quad$ (Zhang

2011)

4

(Hussain \& Entrepreneursh

Othman, 2013)

ip Module in

Community

Universitys

5

(Milla, 2013)

Penididkan

Kewirausahaa

n: Sebuah

Alternatif

Mengurangi

Pengangguran

Terdidik dan

Pencegahan

Korupsi
Joornal of Taking into practice, constructing a good Chinese entrepreneurial environment, Entrepreneur strengthening the entrepreneurial coach ship lecturer and establishing the entrepreneurial consultancy team as well as spreading the entrepreneurial researches.

International Transforming the teaching learning Journal of culture, improving the skill and Trade, economic and Finance

Jurnal Al-Ta'lim knowledge obtained, providing the guidance for the teacher to develop the entrepreneurial behavior.

Through the tridarma perguruan tinggi (Teaching, research and community dedication). The lecturers transfer the entrepreneurial value through the teaching learning process. The research conducted by the lecturer may provide an opportunity for the students to access the field laboratory; the lecturer can involve the students into the innovative community dedication. Therefore, the entrepreneurship education in the basis of science and technology will be developed.

The existences of IbIKK.

6
(Sentoso, 2012) Mewujudkan

Perguruan

Tinggi

Seminar

Entrepreneur

ship

di

Mengembangk

an

Unipdu

Jombang

Entrepreneursh

ip Berkarakter

Dalam

Menghadapi

Persaingan

Global

(1) conducting the workshop, entrepreneurial training for the active students and alumni, (2) Transforming the education curriculum to be in line with the new paradigm facing the global competitions in the need of education nowadays.

,(3) the entrepreneurship award program in the form of business plan or entrepreneurial expo, (4) the human resource development of lecturer, establishing the center for entrepreneurship, the cooperation with DUDI and initiating the students workshop unit.

7 (Eriawaty dan Peran Mata jurnal Profit Fitriyanti, 2016) Kuliah

Kewirausahaa

n dalam

Menumbuhkan
Implemented through the subjects which emphasize more on the theory deepening and direct practice. A part from this, the entrepreneurship education can also be implemented in the tridarma PT, they are ISSN 1927-6044 E-ISSN 1927-6052 


\begin{tabular}{lll}
\hline & Jiwa & \\
& Wirausaha & \\
& Mahasiswa & \\
Pendidikan & \\
& Ekonomi & \\
$8 \quad$ (Pratama, 2010) & Mencari & Binus \\
& Bentuk & Business \\
& Mengajar & Review \\
& Entrepreneursh & \\
& ip & \\
& Perguruan & \\
& Tinggi &
\end{tabular}
9 (Merle Kuttim
at.al, 2013) entrepreneursh ip education at Universitas

level

Students

Entrepreneuria education, research and community dedication.

The entrepreneurship education is carried out by establishing the entrepreneurship center that designs the strategies and concept of the entrepreneurship teaching: (1) case studies, business case studying like the case of google corp leaving China due to high degree of hacking, (2) the speech by the guest speaker (practical) form the business world delivered at the first or general lecturing. The speaker can the one of young businessman

In order that the interview and discussion can be held. (3) The teaching of project design and consultation, (4) the learning of venture plan writing as the final assignment. This part is carried out by integration all aspects of product innovation, financial projection, capital, product and service marketing, market analysis, employee and the permits. (5) the business start up coaching. The students will be trained to be the real businessman by the entrepreneur lecturer.

(6) the teaching through computer simulation as a miniature of business world. Taking an example is the using of http://www.tombongantuk.com. This game will take the students into the business world as a new comer. (7) the study visit learning method to the enterprise company in order to have a direct observation on the business activity and process. (8) the playing of video or short movie about the entrepreneurship. (9) the support in extracurricular activity, (10) the similar perception among lecturer. (11) entrepreneurship integrated curriculum. (12) the clustering of the new students based on their skills and talents of entrrpreneurship.

Procedia Conducting the general course about the Sosial and entrepreneurship, financial attempts, Behavioral family enterprise, social family entrepreneurship, business plan and network opportunity. 
Intentions

10

(Ratih Indriyani, 2017)

11 (Siswoyo, 2009)

Pengembangan
Jiwa
Kewirausahaa
$\mathrm{n}$ di Kalangan
Dosen dan
Mahasiswa
Entrepreneursh ip terhadap Entrepreneuria 1 Intention melalui Entrepreneur Motivation sebagai Mediasi pada Mahasiswa Tinggi Swasta di Surabaya
BISMA The university lecturers are obliged to (Bisnis dan conduct more practical than theory.

Fakultas Ekonomi Universitas Negeri Malang

(1) the systematical and well organized entrepreneurship lecturing with the adequate SKS, (2) KKN- the attempt that provide the students to posses ability, skill, managerial expertise, technology and innovation adoption, the marketing expertise through the direct experience in the business world, (3) Business consultation clinic and job-placement center (KBPK) - a US-AID and HEDS joint donor program which is a development of the consultation center for the micro and medium entrepreneurs. This is an activity providing the service for the university alumnus who have passions to be new employer, or the micro enterprises that have been involved in the business sector.

The KBPK also provides the consultation in order to teach the lecturer to have practical experience in the business world. It allows the access in to the material and financial source, market, information and the establishment of working network. (4) The entrepreneurial internship. This program is an activity where the students are involved as the real employer at the micro and medium enterprise in order to have some practical experiences in terms of problems identification, management, marketing and technology. The internship also create the link and match between the university and the micro DUDI and the lecturer as the supervisor. (5) the students alternative work. This program attempts to relate the students' knowledge and the business understanding. The production skill must be integrated with the business understanding. This program is 
prioritized on the students' production activity as an integral part of the intra or extracurricular activity.

(6) the new entrepreneurship incubation. This program is a university joint program with the ministry of micro enterprise coaching which is organized by the a number of limited staffs that offers a certain package for the students covering the infrastructures, IT access opportunity, marketing management, the establishment of working network among the employees and developers and also the development of research product commercially. This student entrepreneur program is developed by dirjen dikti in 2019. (7) Workshop role models by motivating the students and its graduates that to become an entrepreneur has something to do with the opportunity, freedom and life satisfaction factor. (8) the availability of entrepreneur advisor lecturer. This is a strategic role in growing the entrepreneurship for the students not only in the cognitive aspect but also in the practical ones.

$\begin{array}{lll}\text { (Wiratno, 2012) } & \text { Pelaksanaan } & \text { Jurnal } \\ & \text { Pendidikan } & \text { Pendidikan } \\ & \text { Kewirausahaa } & \text { dan } \\ & \mathrm{n} \quad \text { Di } & \text { Kebudayaan } \\ & \begin{array}{l}\text { Pendidikan } \\ \text { Tinggi }\end{array} & \\ & \end{array}$

(1) delivering the entrepreneurship material by conducting the learning by doing method instead of simulation. (2) Conducting a curriculum updates oriented on the demand driven such as academic knowledge, analitical, managerial and comunication skill. (3) increasing the lecturer competency. (4) providing the additional skill and adaptation skill as well as the socialization skill (soft skill) toward the working atmosphere and posses the life-long education passion. (4) conducting a minimum service standard in implementing the entrepreneurship education to achieve an optimal goal. (5) increasing the application of keppres number 62009 about the creative economy with all required components such as (a) the evaluation and the empowerment of KBPK program, (b) It is necessary that the university conduct a well-systematic plan, step by step and continuo in order to provide the supporting infrastructures for the success of the implementation of entrepreneurship education at numerous 
13

(Lubis, 2015)

14

(Nur

2015)
The

" TRIPLE-I "

Learning

Model

Entrepreneursh

ip Education in

Indonesia:

Where Do We

Go From

Here ? study program and conducting the coordination or networking with the DUDI as the university stakeholder and alumnus empowerment.

International The entrepreneurship education is Journal of conducted in 3 models, they are: (1) the Arts \& "power of one nation" challenge, a Sciences model applied through the mentor scheme provided by the guest and teaching lecturer. This power will bring about variety fields of entrepreneurship such as technopreneur, sociopreneur, edupreneur, creativepreneur and digipreneur. (2) the financial aid challenge, that is regarded as the problems for all entrepreneurship education stake holders. Regarding this, the strong commitment and support of the government is highly required as a process of designing the future of Indonesia by teaching the entrepreneurial generation. (3) The "world class label" effect, which contributes greatly to the success of implementation of entrepreneurship education by establishing the international cooperation. Above all, the most essential points are the commitment, bravery and the brilliant ideas of the lecturer. While the obstacles in the implementation are found in terms of the government funding, the poor mastery of foreign languages and the human recourse commitment.

The entrepreneurship education is applied through the Technical and Vocational Education and Training (TVET). The entrepreneurial education curriculum has always to be developed so as to be able to increase the entrepreneurial culture. Thus, it is able to rise up the students' passion in determining the entrepreneurship as the future carrier field. The government involvement can be done through the provision of facility to motivate the society in general and youth in specific

Pendidikan kewirausahaan dilakukan melalui Technical and Vocational Education and Training (TVET),

15 (Chengalvala et Intentions Towards nternational The entrepreneurship education in the Journal of university is carried out by organizing 


$\begin{array}{lll}\text { Social } & \text { Research } & \begin{array}{l}\text { the programs, activities and workshops } \\ \text { Entrepreneursh }\end{array} \\ \text { ip Among } & \text { h } & \begin{array}{l}\text { related to the entrepreneurship, creating } \\ \text { the real business experience. Raising the }\end{array} \\ \text { University } & \text { copernicus } & \begin{array}{l}\text { support from family, colleagues and } \\ \text { religious figures }\end{array} \\ \begin{array}{l}\text { Students in } \\ \text { India }\end{array} & & \end{array}$

From the fifteen literature reviews of articles above, it is generally found that there are some kinds of model, method and strategy of entrepreneurship implementation at the university. This is mentioned by the writers as the formula in implementing the entrepreneurship education at university.

The formula can be described as follow:

\subsubsection{Stratetgy of Entrepreuneurship Education Implementation at University (Method and Strategy)}

Based on the finding of the literature review above, it is found that the model, method and strategy of entrepreneurship education implementation at university are carried out through the curriculum reform, extracurricular and entrepreneurship design, extracurricular lecturer human resource empowerment, adequate infrastructure, the financial support, the entrepreneurship program design, the alumni empowerment, cooperation with stakeholders and full support from the government that can be elaborated as follow:

\subsection{The Implantation of Entrepreneurship Education Program through the Curriculum Reformation and Integration}

The implementation of entrepreneurship education program through the curriculum reformation and integration is done by transforming the curriculum and initiating the entrepreneur subject (Eriawaty and Fitriyanti, 2016; Patrick Premand at,al,2016;Pratama,2010;Sentoso,2012), conducting teaching- learning process and transferring the entrepreneurial values (Milla, 2013), designing the strategy of entrepreneurship teaching concept (Pratama, 2010), the learning of venture plan writing as the final assignment, the learning of business start up (coaching) conducted by the entrepreneur lecturer, the teaching trough computer simulation as a media to take the students into the business world like the using of the game available at the http://www.tombongantuk.com, the Study Visit to DUDI learning method, the launching of entrepreneurship short movie (Pratama, 2010). Conducting a systematical entrepreneurship lecturing (Siswoyo, 2009), delivering the entrepreneurship learning material through "learning by doing" approach instead of simulation. (2) conducting the curriculum updates by the demand driven- orientation such as knowledge, analytical skill, managerial and communication skill (Wiratno, 2012)

The model of entrepreneurship education implementation through the curriculum reformation and integration can be seen in the following picture:

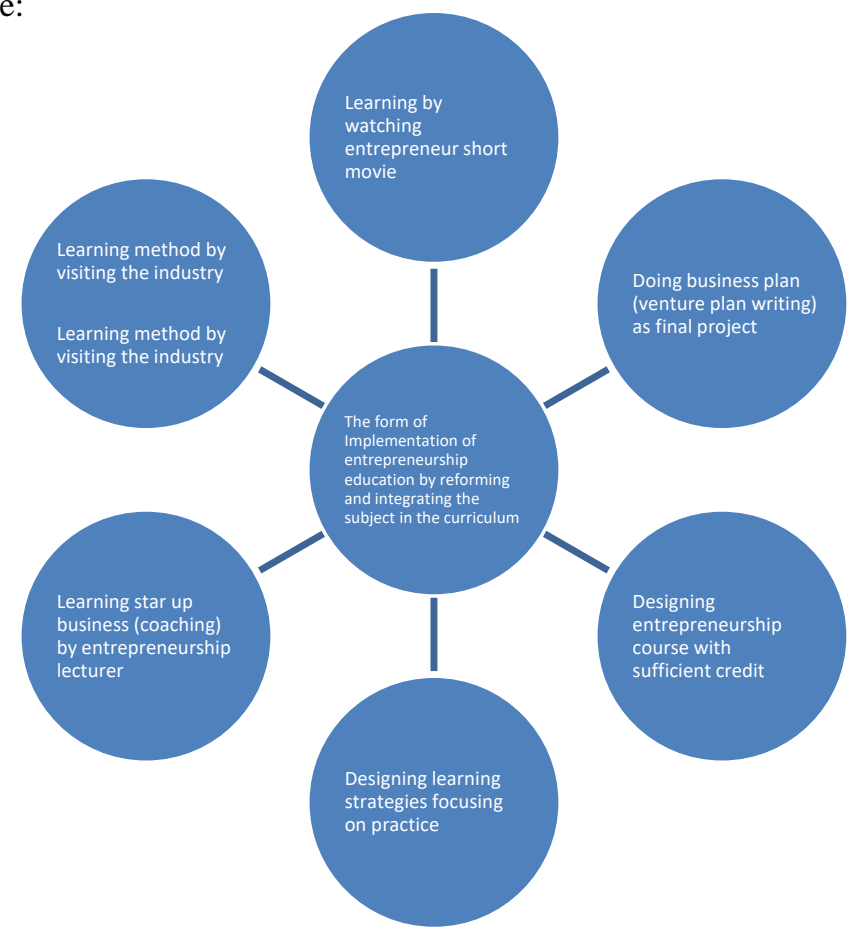




\subsection{The Implementation of Entrepreneurship Education through the Extracurricular Activity}

In addition to intracurricular, the entrepreneurship education is also obligated in the extracurricular (Slamet, 2019). The extracurricular activity is required in the implementation of entrepreneurship education at university as a supporting activity in order to strengthen the intracurricular activity. Besides, it also initiates the entrepreneur activity within the extracurricular as an attempt to achieve the success goal of Indonesian education.

\subsection{The Implementation of Entrepreneurship Education through the Human Resource Empowerment}

The human resource empowerment of lecturer and trainer, (Milla, 2013), (Sentoso, 2012). The lecturer similar mind set perception (Pratama,2010), the high competency of lecturer and the ability to conduct more practical than theoretical learning, the lecturers have strategic role in the teaching effort (Ratih Indrayani, 2017) (Siswoyo, 2009), improving the competency of lecturer (Wiratno, 2012), The "Power of one nation" challenge, by the mentor scheme formula delivered by the guest lecturer and fix lecturer. This power will bring about numerous entrepreneurship sectors such as technopreneur, sociopreneur, ecopreneur, edupreneur, creativepreneur and digipreneur (Lubis, 2015)

To achieve these goals, is necessary that the lecturer should be able to teach the entrepreneurship education in order that the students can obtain the role model in understanding the teaching subject as well as the direct practice.

\subsection{The Implementation of Entrepreneurship Education through the Provision of Education Infrastructure}

Providing the infrastructures, such as field laboratory (Milla, 2013), providing the incubation for the new employer. This incubator program is a university joint cooperation with the ministry office of micro enterprises coaching, which is organized by the number of limited staffs that offer s a package for the employer, students and alumnus such as infrastructure, the IT access opportunity, consultancy service (technology, management and marketing aspects), the working network among employers and the research product development for the commercial production. This program is developed by dirjendikti in 2019 as a student entrepreneur program (Siswoyo, 2009). The involvement of government through the facility provision to motivate the community in general and youth in specific (Nur et al.2015).

3.7 The Implementation of Entrepreneurship Education through the Research Strengthening and Community Dedication

Conducting research and innovative dedication that involves student (Milla,2013), (eriawaty and Fitriyanti,2016), $\mathrm{KKN}$ - an attempt to empower the students with the ability, skill, management expertise, technology innovation adoption and marketing skill through the field experience in the business world (Siswoyo, 2009).

\subsection{The Implementation of Entrepreneurship Education through the Provision of Financial Support}

The financial aid challenge is the problem for all of entrepreneurship education executors. It is necessary to have the strong commitment of the government in order to support the implementation of entrepreneurship education as a process creating the future of Indonesia by teaching the entrepreneur generation (Lubis, 2015)

\subsection{The Implementation of Entrepreneurship Education through Program Initiative}

Initiating the entrepreneurship based program such as technology and science for innovation and University creativity (IbIKK) (Milla, 2013), conducting workshop and entrepreneurship training for active students and alumnus (Merle Kuttim at.al, 2013; Sentoso, 2012), role-models workshop by motivating the students and alumnus that to be entrepreneur is all about the opportunity, freedom factor and life satisfaction factor, Establishing entrepreneurship center, establishing student business unit (Sentoso, 2012). entrepreneurship award program, Speech, stadium general, seminar or talk show delivered by the guest speaker from the business world (Pratama, 2010), initiating the entrepreneurship talent program and clustering of new students recruitment (Pratama, 2010), KKN- the effort of empowering the students with ability, skill, management expert, innovation and technology adoption, marketing expert through the field experience in the business sector, (3) the business consultation clinic and job-placement center (KBPK). This US-AID and HEDS donor program provides a service for the alumni who have ambitions to be new entrepreneurs or the micro entrepreneurs who have been involved in the business sector. KBPK also educates the teaching staffs through consultation in order that they can obtain the practical experience in business sector.

In addition, it also unlocks the access to the material source, market, finance, information and working network. (4) Entrepreneur internship. Through this program, the students are taken into the real business life by playing the role as the employee at the micro or medium business scale in order to obtain some practical working experiences regarding the problem identification, problem analysis, problem solving, management, marketing and technology. The internship also provider the link and match among the university and micro and medium DUDI, with the guidance of teaching staffs as supervisors. (5) Students alternative work. Through this program, the students' knowledge and Published by Sciedu Press 
technology mastery is integrated and combined with the business knowledge.

The production ability is synchronized with the one in the business demand. This program is prioritized for the students' productive activity as an integral part of the intra or extracurricular activity. (6) The new entrepreneurship incubation. This incubator program is a university joint cooperation with the ministry office for the micro enterprise coaching. This program is organized by the number of limited staffs who offer a package for the entrepreneurs, students and alumni such as infrastructures, IT access opportunity, consultation service, working network among the entrepreneurs and the development of research product for the commercial production. This program was developed by the dirjendikti in 2019 as a student entrepreneurs program (Mukhlisuddin Ilyas, 2019) (Siswoyo, 2009).

The entrepreneurship education is done through the technical and vocational education and training (TVET), entrepreneurial education curriculum must always be improved so as to be able to grow the entrepreneurial culture. As a result, it can increase the students' passion and motivation to choose the entrepreneur as their future carrier field (Nur et.al,.2015). The entrepreneurship education at university is conducted by organizing the activity, program and workshop which are interconnected with the entrepreneurship (Chengalvala et, at., 2017).

\subsection{The Implementation of Entrepreneurship Education through the Associates Cooperation Strengthening}

The "world class Label" effect of the university has a significant contribution to the success of the entrepreneurship education implementation by establishing the international cooperation. Somehow, the commitments, bravery and new brilliant ideas of the teaching staff is above all (Lubis, 2015), establishing the cooperation with DUDI (Sentoso, 2012), providing consultation service in terms of technology, management and marketing, working network establishment among the entrepreneurs and developing research product for the commercial production. This program was developed by the dirjendikti in 2019 as a student entrepreneur program (Siswoyo, 2009), gathering the support from family, colleagues and the religious figures (Mukhlisuddin Ilyas, 2019) (Chengalvala et.,al,2017)

\subsection{The Implementation of Entrepreneurship Education through the Alumni Empowerment}

The alumni empowerment provides the additional skills such as live skill, adaptation skill, socialization skill (soft skill) toward the working environment and the passion of life-long education. Attempting a minimum service standard in running the entrepreneurship education program to achieve an optimal pattern goal. Maximizing the application of the Presidential Decree number 6, 2009 about the creative economy covering all required aspects such as (a) the evaluation and empowerment of the KBPK program, (b) It is important that the high education conduct a well-planned, step by step and continue planning in providing the infrastructures to support the success of the entrepreneurship education at a number of Department and building a coordination and cooperation or job network with DUDI as the university partner and alumni empowerment.

While the obstacles are found as follow (1) the preparation and implementation of the entrepreneurship education and the new unit role as the entrepreneur organizer are still considered in optimal. (2) The limit provision of infrastructure provider, working partner, fund and competent lecturer in providing the content of entrepreneurship skill (Abreu \& Grinevich, 2013; Salman, Muhammad Shabbir, 2019), Wiratno, 2012.

\subsection{Implementing Entrepreneurship Education by Requesting Government Support}

It is essential to gain the full support of government for the implementation of entrepreneurship education (Martin, Bruce C. Jeffrey J. McNally,2013). The government involvement through facility support to provide motivation to the community in general and youth in specific (Nur et al., 2015 (Darling-Hammond et al., 2019; Sulaiman, 2015)

\subsection{The Implementation Formula of Entrepreneurship Education at University}

Based on the finding in the articles that the writer has analyzed previously, it can be concluded that the implementation of implementation of entrepreneurship education at university can be done through the formula based on the analysis result from the various journals. The formula can be seen in the following table: 


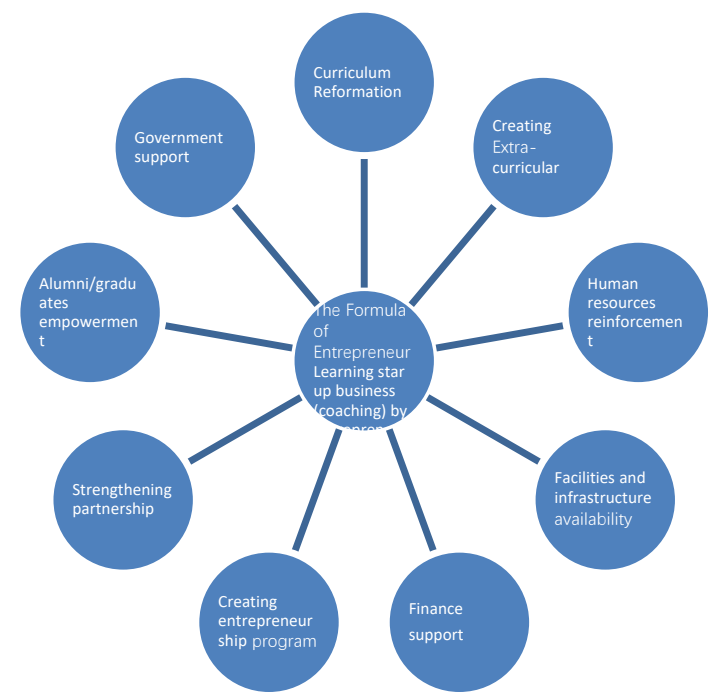

Thus, the entrepreneurship education formula at the university can be defined as the implementation of the whole activities by conducting the curriculum reformation, teaching staff empowerment, inviting the expert guess speaker, the provision of adequate infrastructure and repairmen, the using of proper learning method by enriching the field practice and conducting the innovative activity of Tri Dharma College.

Entrepreneurship Education (Entrepreneurship) is supposed to be an important part of the National Education Program. Entrepreneurship Education is viewed. Not only following the needs of increasing the number of business actors in the country but rather related to the efforts to reduce the number of educated unemployment and increase the competitiveness of Indonesian human resources (Darwanto, 2012; Lukman, 2016; Lyken-Segosebe et al., 2020). Entrepreneurship education includes not only limited to the domain of business economics, but rather the areas of science and profession, including the religious fields, social, educational, political, and others. Now the significance of entrepreneurship education has been realized by education institutions including in the Education Environment Islamic Religious Height (PTKI) (Lukman, 2016; Nur et al., 2015).

Entrepreneurship education in particular serves as a complement (complementary) and as an enabler for the student life skills. Therefore, there are no conceptual, methodological, or aspect barriers to the application of entrepreneurial education in the context of education in the Islamic College of Religion.

\section{Conclusion}

Based on the analysis conducted by the writer above, it can be concluded that the entrepreneurship education at the university can be implemented through the hole formula as a reflection of the university responsibility to the generation. The implementation formula can be done through the curriculum reformation, analysis and development, extracurricular creation, entrepreneur teaching staff human resource strengthening, , the adequate of infrastructure supply, the financial support, the entrepreneurship program creation, the associates cooperation strengthening, the alumni empowerment as well as the full government support. From a number of articles that the writer described above, the mostly implemented formula is done through the program creation (initiation).

The whole formula (kaffah) of the entrepreneurship education at the university can be carried out through the essential dimensions as well as the core activities of the university. By implementing this formula, it can raise the attitudes, habits and passions of the students to be young entrepreneurs as a solution for the unemployment as one of social problems.

Some recommendations for the future literature review analysis are: (1) considering that this research is still too global, it is suggested to use more up -to date articles in order that the knowledgeable of the articles can be obtained,

(2) The database usage should be done in a more extensive scale in order to obtain more articles related to this topic,

(3) there is only one article about the format of entrepreneurship done through the extracurricular that was found on this research. It is hoped that the future researcher could find more articles related to this topic to strengthen the finding of the research. 


\section{References}

Abreu, M., \& Grinevich, V. (2013). The nature of academic entrepreneurship in the UK: Widening the focus on entrepreneurial activities. Research Policy, 42(2), 408-422. https://doi.org/10.1016/j.respol.2012.10.005

Chengalvala, S., Rentala, S., Degree, V. S. R. G., District, K., Pradesh, A., Manager, P., Zone, S., Foundation, P., Leadership, E., Enclave, P., \& Delhi, N. (2017). Intentions Towards Social Entrepreneurship Among University Students in India. International Journal of Research Granthaalayah, 5, 406-413. https://doi.org/https://doi.org/10.5281/zenodo.821710

Darling-Hammond, L., Flook, L., Cook-Harvey, C., Barron, B., \& Osher, D. (2019). Implications for educational practice of the science of learning and development. Applied Developmental Science, 1-44. https://doi.org/10.1080/10888691.2018.1537791

Darwanto. (2012). Peran Entrepreneurship Dalam Mendorong Pertumbuhan Ekonomi Dan Peningkatan Kesejahteraan Masyarakat. In Diseminasi Riset Terapan Bidang Manajemen \& Bisnis Tingkat Nasional. https://core.ac.uk/download/files/379/11735270.pdf

Eriawaty dan Fitriyanti. (2016). Peran Mata Kuliah Kewirausahaan dalam Menumbuhkan Jiwa Wirausaha Mahasiswa Pendidikan Ekonomi. Jurnal Profit, 3, 21-25.

Hussain, R., \& Othman, N. (2013). Entrepreneurship Module in Community Colleges. International Journal of Trade, Economic and Finance, 4(6), 2-6. https://doi.org/10.7763/IJTEF.2013.V4.330

Lubis, R. L. (2015). The “ TRIPLE-I " Learning Model of Entrepreneurship Education in Indonesia: Where Do We Go From Here? International Journal of Arts \& Sciences, 08(07), 233-264.

Lukman, F. dkk. (2016). PTKI Entrepeneur (Gagasan dan Praktik). Kurnia Kalam Semesta.

Lyken-Segosebe, D., Montshiwa, B., Kenewang, S., \& Mogotsi, T. (2020). Stimulating academic entrepreneurship through technology business incubation: Lessons for the incoming sponsoring university. International Journal of Higher Education, 9(5), 1-18. https://doi.org/10.5430/ijhe.v9n5p1

Merle Kuttim at.al. (2013). entrepreneurship education at Universitas level and Students Entrepreneuria Intentions. Procedia Sosial and Behavioral Sciences, 658-668. https://doi.org/10.1016/j.sbspro.2013.12.910

Milla, H. (2013). Penididkan Kewirausahaan: Sebuah Alternatif Mengurangi Pengangguran Terdidik dan Pencegahan Korupsi. Jurnal Al-Ta'lim, (6), 465-471. https://doi.org/10.15548/jt.v20i3.44

Mukhlisuddin Ilyas, et. al. (2019). Leadership Tranformation: Study of Islamic Boarding School (Dayah) in Aceh Province of Indonesia. Journal of Etrepreneurship Education, 22(2), 1-5.

Nur, W., Ibrahim, A., Bakar, A. R., Asimiran, S., Mohamed, S., \& Zakaria, N. S. (2015). Impact of Entrepreneurship Education on the Entrepreneurial Intentions of Students in Technical and Vocational Education and Training Institutions (TVET) In Malaysia. International Education Studies, 8(12). https://doi.org/10.5539/ies.v8n12p141

Patrick Premand at.al. (2016). Entrepreneurship Education and Entry into Self Employment Among university Graduates. Wold Development, 77, 311-327. https://doi.org/10.1016/j.worlddev.2015.08.028

Pratama, B. (2010). Mencari Bentuk Mengajar Entrepreneurship Pada Perguruan Tinggi. Binus Business Review, 1(2), 293-306. https://doi.org/10.21512/bbr.v1i2.1076

Ratih Indriyani. (2017). Pengaruh Entrepreneurship Education terhadap Entrepreneurial Intention melalui Entrepreneurial Motivation sebagai Media pada mahasiswa Perguruan Tinggi Swasta di Subaya. Bisnis Dan Manajemen, 10(1). https://doi.org/10.26740/bisma.v10n1.p26-46

Salman, Muhammad Shabbir, etc. (2019). 4th Industrial Revolution and TVET: The Relevance of Entrepreneurship Education for Development. Opcion, 35, 11-21.

Schuitema, Jaap, Geert ten Dam, and W. V. (2008). Teaching strategies for moral education: A review. Journal of Curriculum Studies, 40.1, 69-89. https://doi.org/10.1080/00220270701294210

Sentoso, E. (2012). Mewujudkan Perguruan Tinggi Mengembangkan Entrepreneurship Berkarakter Dalam Menghadapi Persaingan Global. Seminar Entrepreneurship Di Unipdu Jombang.

Sipitanou, A. A., \& Papagiannis, G. D. (2013). Education, Entrepreneurship and Entrepreneurial Activation: A Challenge for All. International Journal of Arts \& Sciences, 6(2), 139-149.

Siswoyo, H. B. B. (2009). Pengembangan Jiwa Kewirausahaan di Kalangan Dosen dan Mahasiswa. Fakultas 
Ekonomi Universitas Negeri Malang, 1-14.

Sulaiman. (2015). Classroom Management and the Implications to Quality of Learning. Jurnal Ilmiah Peuradeun, $3(3), 431-440$.

Sulaiman. (2017). The Implementation of Humanistic Learning at Darul Aman Islamic High School in Aceh Besar. Ulumuna, 21, 151-172. https://doi.org/10.20414/ujis.v21i1.1161

Wiratno, S. (2012). Pelaksanaan Pendidikan Kewirausahaan Di Pendidikan Tinggi. Jurnal Pendidikan Dan Kebudayaan, 19(4), 453-466. https://doi.org/10.24832/jpnk.v18i4.101

Zhang Lili. (2011). Comparative study of China and USA' s colleges entrepreneurship education from an international perspective. Joornal of Chinese Entrepreneurship, 3(3), 185-194. https://doi.org/10.1108/17561391111166966

\section{Copyrights}

Copyright for this article is retained by the author(s), with first publication rights granted to the journal.

This is an open-access article distributed under the terms and conditions of the Creative Commons Attribution license (http://creativecommons.org/licenses/by/4.0/). 